\title{
Antioxidative and Immunomodulatory Effects of A-Lipoic Acid in Rat Colitis Model Induced by Acetic Acid
}

\author{
Asetik Asit ile Oluşturulan Deneysel Rat Kolit Modelinde A-Lipoik Asitin Antıoksidan ve İmmünomodülatör \\ Etkileri
}

Bilal Ergül ${ }^{1}$, Zeynal Doğan², Murat Sarıkaya², Levent Filik², Özlem Gül Utku¹, Mehmet Gönültaşs ${ }^{3}$ Sema Hücümenoğlu ${ }^{3}$, Berrak Güven ${ }^{4}$, Murat Can ${ }^{4}$

${ }^{1}$ Kırıkkale University, Faculty of Medicine, Department of Gastroenterology, Kırıkkale, Turkey

${ }^{2}$ Ankara Education and Research Hospital, Department of Gastroenterology, Ankara, Turkey

${ }^{3}$ Ankara Education and Research Hospital, Department of Pathology, Ankara, Turkey

${ }^{4}$ Zonguldak Karaelmas University, Faculty of Medicine, Department of Medical Biochemistry, Zonguldak, Turkey

\section{ABSTRACT}

Aim: Benefit of $\alpha$-Lipoic acid (ALA) was previously shown in rat-colitis model via suppression of neutrophil accumulation, preservation of endogenous glutathione and inhibition of reactive oxidant generation. Ulcerative colitis is a chronic inflammatory condition of the colon and cytokines (such as TNF- $\alpha$, IL-1 $\beta$ and TGF- $\beta$ ) are crucial components of these inflammatory pathways. Hence, the present study was undertaken to evaluate the antioxidative and immunomodulatory effects of ALA on experimental colitis model induced by acetic acid in Wistar albino rats.

Methods: Mice received either a control diet or ALA-supplemented diet for $14 \mathrm{~d}$. Colitis was induced by acetic acid administration at $7^{\text {th }}$ day. Mucosal damage and the activation of immune cells and cytokines were determined by macroscopic score, histological score, tissue cytokine levels (TNF- $\alpha$, IL-1 $\beta$ and TGF- $\beta$ ). Anti-oxidant effect of ALA was determined by Malondialdehyde, and total antioxidative status.

Results: Disease activity Index was significantly higher in colitis group compared to control, ALA and ALA-colitis groups $(p<0.001)$. No significant difference was found between DAI of control, ALA and ALA-colitis groups. The inflammatory mediators, TNF- $\alpha$ and IL-1 $\beta$, and MDA were elevated in colitis group compared to other groups ( $p<0.001, p<0.001$ respectively). TGF$\beta$ and total antioxidative status were significantly lower in colitis group $(\mathrm{p}<0.001)$.

Conclusion: ALA may possibly have some therapeutic usefulness in the management of ulcerative colitis.

Key Words: $\alpha$-Lipoic acid, ulcerative colitis, TNF- $\alpha$, IL-1 $\beta$, TGF- $\beta$, MDA, TAS, antioxidative effect

Received: 08.14.2017
Accepted: 02.15.2018

\section{ÖZET}

Amaç: A-Lipoik asidin (ALA) faydası, sıçan-kolit modelinde, nötrofil birikiminin baskılanması, endojen glutatyonun korunması ve reaktif oksidan oluşumunun inhibisyonu yoluyla daha önce gösterildi. Ülseratif kolit, kolonun kronik enflamatuar bir durumudur ve sitokinler (TNF- $\alpha$, IL-1 $\beta$ ve TGF- $\beta$ gibi) bu enflamatuar yolakların önemli bileşenleridir. Bu nedenle, Wistar albino sıçanlarda asetik asit tarafından indüklenen deneysel kolit modeli üzerinde ALA'nın antioksidan ve immünomodülatör etkilerini değerlendirmek için bu çalışma yapıldı.

Yöntemler: Farelere 14 gün boyunca kontrol diyeti veya ALA destekli diyet uygulandı. Kolit 7. günde asetik asit uygulaması ile indüklendi. Mukozal hasar ve immün hücrelerin ve sitokinlerin aktivasyonu, makroskopik skor, histolojik skor, doku sitokin seviyeleri (TNF- $\alpha$, IL-1 TG ve TGF- $\beta$ ) ile belirlendi. ALA'nın antioksidan etkisi malondialdehit ve toplam antioksidan durum ile belirlendi Bulgular: Kolit grubunda hastalık aktivite indeksi kontrol, ALA ve ALA-kolit gruplarına göre anlamlı olarak yüksek bulundu ( $p<0.001)$. Hastalık aktivite indeksi, kontrol, ALA ve ALA-kolit grupları arasında anlamlı fark bulunmadı. Enflamatuar mediatörler olan TNF- $\alpha$, IL-1 ve MDA kolit grubunda diğer gruplara göre artmıştı (sırasıyla $p<0.001, p<0.001$ ). TGF- $\beta$ ve total antioksidan durum kolit grubunda anlamlı derecede düşüktü $(p<0.001)$ Sonuç: ALA, ülseratif kolit tedavisinde bazı terapötik faydalara sahip olabilir.

Anahtar Sözcükler: $\alpha$-Lipoik asit, ülseratif kolit, TNF- $\alpha$, IL-1 $\beta$, TGF- $\beta$, MDA, TAS, antioksidan etki

Geliş Tarihi: 14.08 .2017

Kabul Tarihi: 15.02.2018 


\section{INTRODUCTION}

Ulcerative colitis (UC) is a chronic inflammatory bowel disease of unknown origin, which elicits the risk of colorectal cancer, the third most common malignancy in humans (1). Current literature suggests that multiple genetic, environmental and immune factors take place in the pathogenesis and progression of the disease (2). It has been well known for a long time that inflammatory mediators such as cytokines, eicosanoids and reactive oxygen metabolites are crucial components of the inflammatory pathways $(3,4)$. Because there is no known medical cure for ulcerative colitis, the therapeutic regimens are aimed at reducing the signs and symptoms associated with the disorder as well as the induction and maintenance of remission. Although, standard treatment of ulcerative colitis depends on the severity, localization and extend of involvement, drugs that contain 5-aminosalicylic acid compounds and glucocorticoids are the major components of initial treatment regimens because of immunoregulatory and anti-inflammatory effects (5). On the other hand, many patients do not respond to the currently available options and demonstrate significant side effects on prolonged use. Therefore, new therapeutic strategies are awaited.

$\alpha$-Lipoic acid (1,2-dithiolane-3-pentanoic acid) (ALA) is a natural compound essential cofactor for the oxidative decarboxylation of pyruvate to acetylCoA, the critical step between glycolysis and the citric acid cycle (6). ALA is a naturally occurring dithiol compound enzymatically synthesized from octanoic acid in the mitochondrion. In addition to synthesis, ALA is absorbed intact from dietary sources, taken up and reduced in mitocondria to the potential antioxidant dihydrolipoic acid (6,8-dithiooctanoid acid, DHLA) (7). There is growing evidence that orally delivered LA may not be used as a metabolic cofactor but, instead elicits a unique set of biochemical activities with potential pharmacotherapeutic value against a host of pathophysiologic insults (8). ALA/DHLA redox couple is one of the most powerful antioxidant systems and is known to scavenge hydroxyl radicals, singlet oxygen, hydrogen peroxide, hypochlorous acid, peroxynitrite and nitric oxide $(9,10)$. Therefore, it appears that ALA could be a potential agent in the prevention of different diseases that may be related to an imbalance of cellular oxidoreductive status. ALA has been reported to protect against oxidative injury in various disease processes including neurodegenerative disorders (11), poylneuropathy (12), hypertension $(13,14)$, atherosclerosis (15), dyslipidemia $(16,17)$, diabetes mellitus $(18)$ and insulin resistance (19) and hepatic disorders (20). Recently, it has also been shown that ALA inhibits NFkB activation, a critical inflammation signaling pathway, independent of its antioxidant function (21). However, there are scanty of data that investigate the protective role and mechanism of ALA in UC. Hence, the present study was undertaken to evaluate the antioxidative and immunomodulatory effects of ALA on experimental colitis model induced by acetic acid in Wistar albino rats.

\section{MATERIALS and METHODS}

ALA was provided in the form of its commercial preparation by GNC (General Nutrition Center), Pittsburgh, USA. The concentration of ALA was adjusted so that the required dose of $100 \mathrm{mg} / \mathrm{kg} /$ day was found in $1 \mathrm{ml}$ of solution/suspension.

Animals

Twenty male Wistar-Albino rats, weighing 200-250 g each, were obtained from Ankara Education and Research Hospital of Experimental Research Laboratory (Ankara, Turkey). All experiments were carried out in accordance with the National Institute of Health Guidelines for the care and use of Laboratory Animals. The rats were housed individually in standard rat cages in the animal room, which was maintained on a $12 \mathrm{~h}$ light/12 $\mathrm{h}$ dark cycle at $21-22 \circ \mathrm{C}$. All rats were fed with standard laboratory pellet chow and water ad libitum. Body weights of the animals were monitored throughout the study. The structure of this study and animal experimental procedures were approved by the Ethical Committee of Ankara Education and Research Hospital.

\section{Acute Colitis Induction and Treatment Protocols}

Acute colitis was induced by the intrarectal administration of $1 \mathrm{ml}$ of a $4 \%$ solution of acetic acid. After rats were anesthetized with a dose of $75 \mathrm{mg} / \mathrm{kg}$ ketamin injected intraperitoneally, a flexible soft $6 \mathrm{~F}$ pediatric catheter was inserted into the anus for $6 \mathrm{~cm}$ and acetic acid was slowly infused into the distal colon. Before taking the catheter out, $2 \mathrm{ml}$ of air was applied in order to spread acetic acid completely in the colon. All rats were maintained in head down position for 30 seconds to prevent leakage. ALA $100 \mathrm{mg} / \mathrm{kg} / \mathrm{day}$ was given into stomach by a soft $6 \mathrm{~F}$ pediatric catheter in accordance with previous studies. Rats were randomly assigned to four groups of five animals each as follows:
Group 1 (Control; $n=5$ ) were allowed free access to food and water ad libitum for 14 days. Group 2 (ALA; $n=5$ ) were allowed free access to food, water ad libitum and $100 \mathrm{mg} / \mathrm{kg} /$ day ALA for 14 days. On the $8^{\text {th }}$ day, $2 \mathrm{ml}$ saline was administered by rectal way.

Group 3 (ALA-Colitis; $n=5$ ) were allowed free access to food, water ad libitum and $100 \mathrm{mg} / \mathrm{kg} /$ day ALA for 14 days. On the $8^{\text {th }}$ day $1 \mathrm{ml}$ saline and 1 $\mathrm{ml} \% 4$ acetic acid was administered by rectal way.

Group 4 (Colitis; $n=5$ ) were allowed free access to food, water ad libitum for 14 days. On the $8^{\text {th }}$ day $1 \mathrm{ml}$ saline and $1 \mathrm{ml} 4 \%$ acetic acid was administered by rectal way.

\section{Disease activity index (DAI)}

The DAl during the period for 7 days after inducing colitis was scored as follows : 0-no weight loss, normal stool consistency, and no rectal bleeding; 1-weight loss (1-5\%), normal stool consistency with no rectal bleeding; 2weight loss (5-10\%), loose stool with no rectal bleeding; 3-weight loss (10$20 \%)$, normal stool consistency with no rectal bleeding; and 4-weight loss (>20\%), diarrhea with gross rectal bleeding (22).

\section{Assessment of Colonic Damage}

All rats were sacrificed by cervical decapitation under general anesthesia on the $15^{\text {th }}$ day. The abdomen was opened and the colon was exposed. The distal $8 \mathrm{~cm}$ of the colon was excised and opened by a longitudinal incision macroscopic scoring. The distal $4 \mathrm{~cm}$ of colon segments were preserved with \%10 formalin for microscopic evaluation while the proximal segments were separated for biochemical analysis. After washing the mucosa with saline solution, the specimens were examined and all visible mucosal damages were assessed macroscopically using the grading scale of Morris et al.(23) as follows: $0=$ no damage; $1=$ localized hyperemia, edema and inflammation without ulcers; $2=$ linear ulcers with no significant inflammation; $3=$ linear ulcer with inflammation at one site; 4=two or more sites of ulceration and inflammation; $5=$ two or more sites of ulceration and inflammation or one major site of inflammation and ulceration extending $>1 \mathrm{~cm}$ along the length of the colon. Additional samples were preserved in $10 \%$ formalin for histological examination. Formalin-fixed colonic samples were embedded in paraffin, and sections were stained with hematoxylin and eosin. The degree of inflammation of the colon was graded from 0 to 11 according to described criteria (24) by taking into consideration (1) loss of mucosal architecture (score 0-3), (2) cellular infiltration (score 0-3) (3) muscle thickening (score 0$3)$, (4) crypt abscess formation (score $0-1$ ), and (5) goblet cell depletion (score 0-1).

\section{Biochemical Analysis}

The proximal $4 \mathrm{~cm}$ of colonic tissue samples were homogenized with Ultra Turrax homogenizer (T25-B, IKA, Labortechnic, Germany) in Tris/Tween buffer (25). Then, the homogenate was centrifuged at $8000 \mathrm{~g}$ at 4 centigrade. The supernatant fluid was taken and TGF- 31 , TNF- $\alpha$ and IL-1 $\beta$ protein concentrations were measured with Lowry method (26). Level of cytokines was performed as $\mathrm{pg} / \mathrm{mL}$.

Tissue TGF-ß1 levels were measured by competitive enzyme immunoassay using ELISA kits (eBioscience, Vienna, Austria) by following the manufacturer's protocol. The intra- and inter-assay CV were less than $6.9 \%$ and $12 \%$ for TGF-ß1.

Tissue TNF- $\alpha$ levels were measured by competitive enzyme immunoassay using ELISA kits (eBioscience, Vienna, Austria) by following the manufacturer's protocol. The intra- and inter-assay CV were less than $5.0 \%$ and $10 \%$ for TNF- $\alpha$.

Tissue IL-1 $\beta$ levels were measured by competitive enzyme immunoassay using ELISA kits (eBioscience, Vienna, Austria) by following the manufacturer's protocol. The intra-and inter-assay CV were less than $10 \%$ and $10 \%$ for IL- $1 \beta$.

Malondialdehide (MDA) levels were assayed with a commercial kit (OxisResearch, CA, USA) which is based on the colorimetric method using Shimadzu UV 1601 spectrophotometer (Shimadzu Corporation, Kyoto, Japan). MDA method is based on the reaction of a chromogenic reagent $\mathrm{N}$ methyl-2-phenylindole (NMPI) with MDA at $45 \mathrm{OC}$. One molecule of MDA reacts with 2 molecules of NMPI to yield a stable carbocyanine dye. NMPI reacts with MDA to form an intensely colored carbocyanine dye with a maximum absorption at $586 \mathrm{~nm}$. The assay with intra- and interassay coefficients of variable less than $5.0 \%$.

TAS (Total antioxidative status) levels were assayed with a commercial kit (Immundiagnostik, Bensheim, Germany) which is based on the colorimetric method using Shimadzu UV 1601 spectrophotometer (Shimadzu Corporation, Kyoto, Japan). The determination of the antioxidative capacity is performed by the reaction of antioxidants in the sample with a defined amount of exogenously provided hydrogen peroxide ( $\mathrm{H} 2 \mathrm{O} 2)$. 
The antioxidants in the sample eliminate a certain amount of the provided $\mathrm{H} 2 \mathrm{O} 2$. The residual $\mathrm{H} 2 \mathrm{O} 2$ is determined photometrically by an enzymatic reaction which involves the conversion of TMB to a colored product. The assay with intra- and interassay coefficients of variable less than $5.0 \%$. Statistical analysis

Data are expressed as mean \pm SE. Statistical analyses were performed by one way ANOVA followed by Tukey's multiple comparison test for levels of TNF- $\alpha$, IL-1 $\beta$, TGF- $\beta$, MDA and TAS and Kruskal-Wallis test was used for disease activity index, macroscopic and microscopic score with the Statistical
Package for Social Sciences version 15.0 (SPSS Inc., Chicago, USA). A p value of less than 0.05 was considered statistically significant.

\section{RESULTS}

Disease activity Index (DAI) was significantly higher in colitis group (group 4) compared to control (group1), ALA (group 2) and ALA-colitis (group 3) groups $(p<0.001)$. No significant difference between DAI of control, ALA and ALA-colitis group (Table 1).

Table 1: Effects of ALA on DAI, macroscopic and microscopic scores, cytokine and antioxidant levels.

\begin{tabular}{lllllll}
\hline & $\begin{array}{l}\text { Control (Group 1) } \\
(\mathbf{n}=5)\end{array}$ & $\begin{array}{l}\text { ALA } \\
\text { (Group 2) } \\
(\mathbf{n}=5)\end{array}$ & $\begin{array}{l}\text { ALA-Colitis } \\
\text { (Group 3) } \\
(\mathbf{n}=5)\end{array}$ & $\begin{array}{l}\text { Colitis } \\
\text { (Group 4) } \\
(\mathbf{n}=5)\end{array}$ & $\mathbf{p}^{*}$ & $\mathbf{p}^{* *}$ \\
\hline DAI & $0 \pm 0$ & $0 \pm 0$ & $0,8 \pm 0,4$ & $2,8 \pm 0,4$ & $<0,001$ \\
Macroscopic score & $0 \pm 0$ & $0 \pm 0$ & $0 \pm 0$ & $4,4 \pm 0,8$ & $<0,001$ \\
Microscopic score & $0,4 \pm 0,4$ & $0,6 \pm 0,4$ & $0,8 \pm 0,4$ & $4,8 \pm 1,1$ & $<0,001$ & $>0,16$ \\
IL-1 $\boldsymbol{\beta}$ & $255,0 \pm 49,2$ & $250,2 \pm 89,8$ & $246,6 \pm 117,5$ & $588,8 \pm 99,7$ & $<0,001$ & $>0,1$ \\
TNF- $\boldsymbol{\alpha}$ & $358,4 \pm 31,6$ & $364,8 \pm 86,6$ & $367,1 \pm 36,4$ & $745,5 \pm 84,5$ & $<0,001$ & $>0,12$ \\
TGF- $\boldsymbol{\beta}$ & $258,0 \pm 47,9$ & $254,9 \pm 71,1$ & $247,2 \pm 33,2$ & $98,6 \pm 15,3$ & $<0,001$ & $>0,44$ \\
MDA & $0,39 \pm 0,08$ & $0,56 \pm 0,25$ & $0,49 \pm 0,11$ & $1,07 \pm 0,69$ & $<0,001$ & \\
TAS & $2,25 \pm 1,14$ & $27,60 \pm 18,46$ & $10,76 \pm 3,68$ & $1,05 \pm 0,01$ & $<0,001$ & \\
\hline
\end{tabular}

DAI: Disease activity index. IL-1 $\beta$ : Interleukin 1 beta. TNF $\alpha$ : Tumor necrosis factor alpha. TGF- $\beta$ : Transforming growth factor beta. Values expressed as mean \pm SE. P* value: Colitis group campared with other groups. P** value: Groups of control, ALA, ALA-colitis compared with each other.

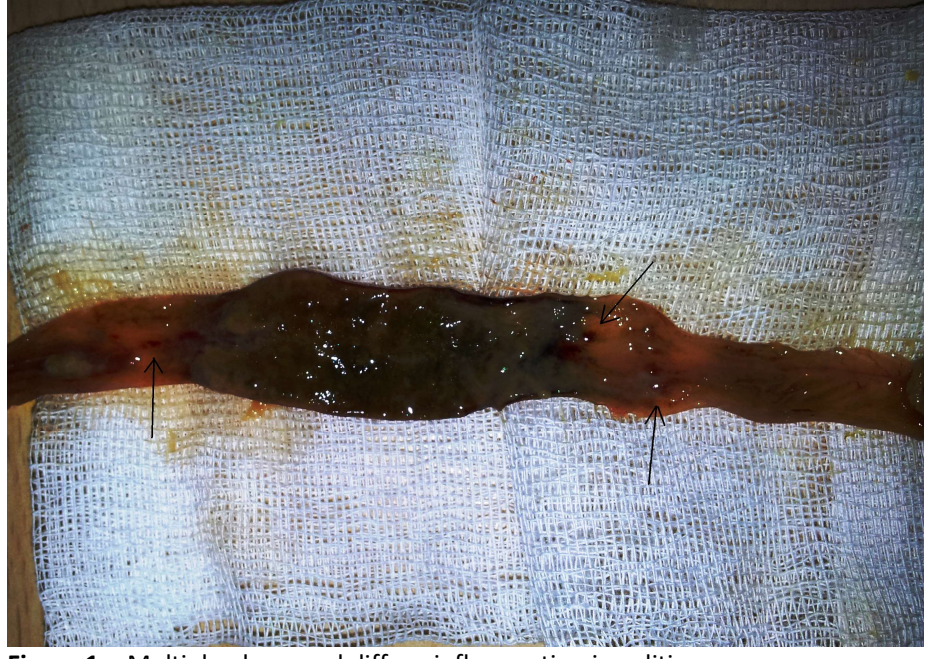

Figure 1a. Multiple ulcers and diffuse inflammation in colitis group

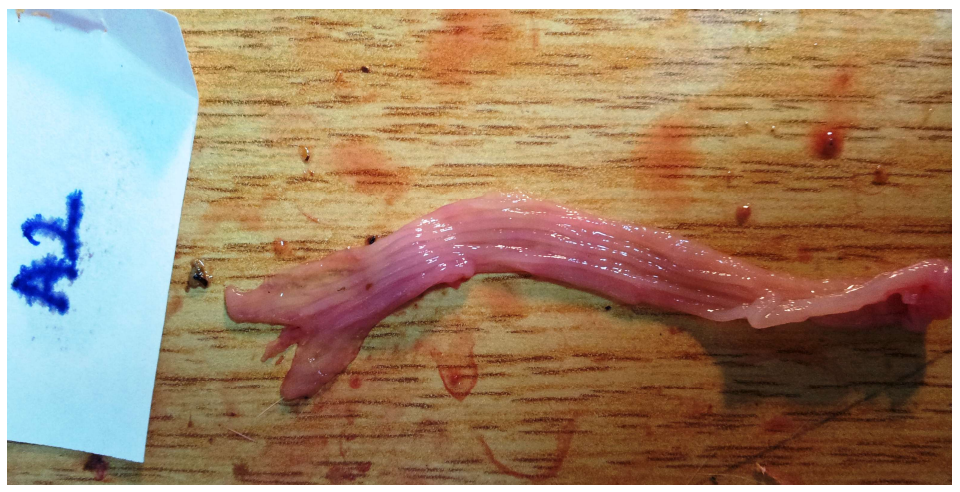

Figure 2a.

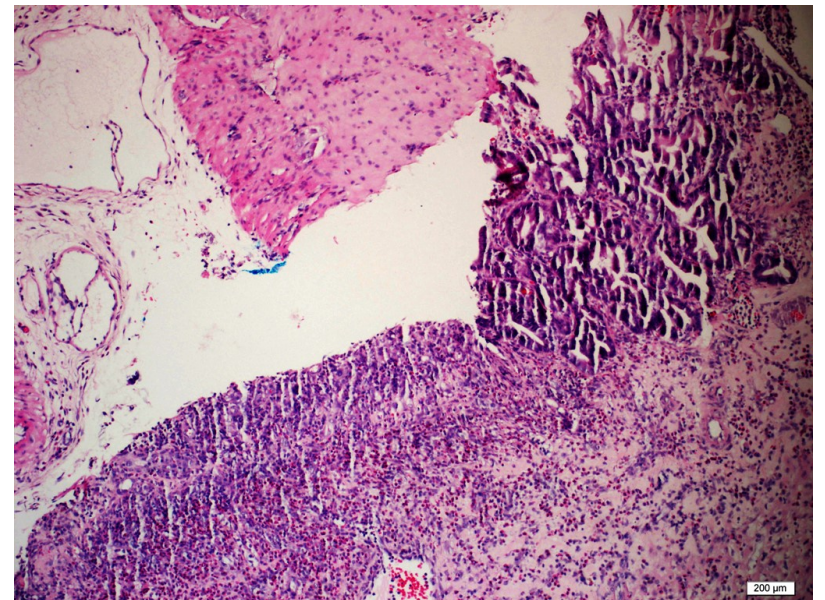

Figure 1b. Loss of epithelial cells with ulceration, goblet cell depletion, inflammatory cells in mucosa and around the crypts that were polymorphonuclear leukocytes and lymphocytes ( $x 400, \mathrm{H}$ and $\mathrm{E}$ )

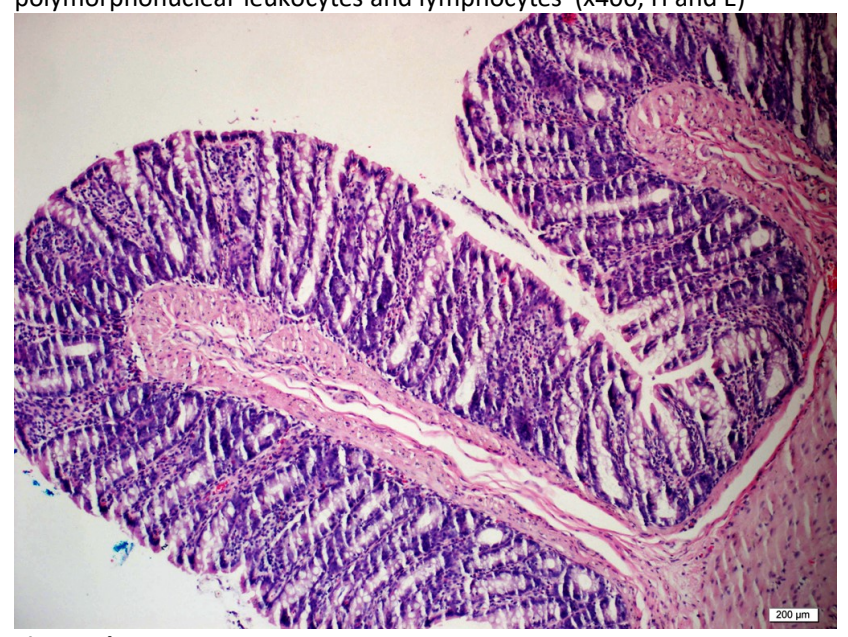

Figure 2b. 


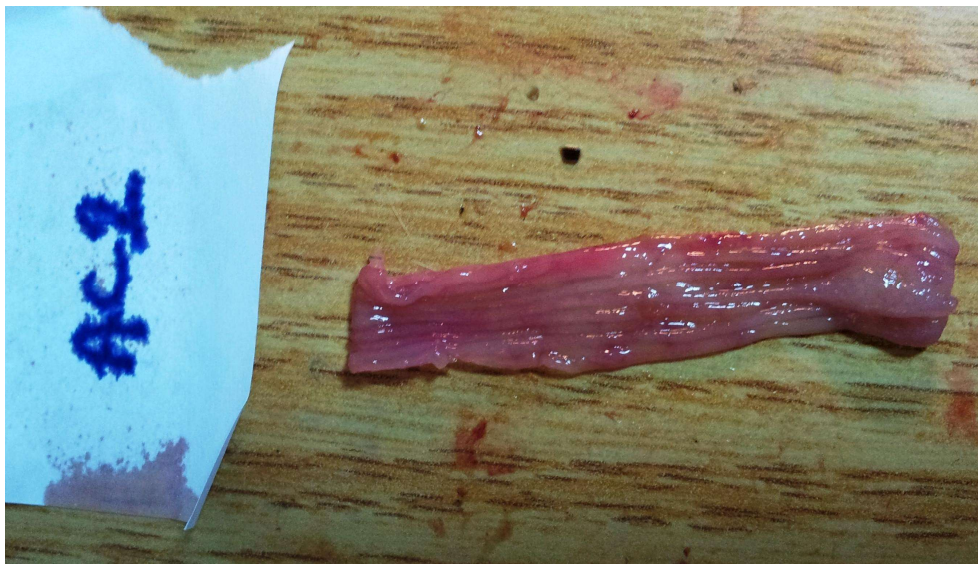

Figure 3a.

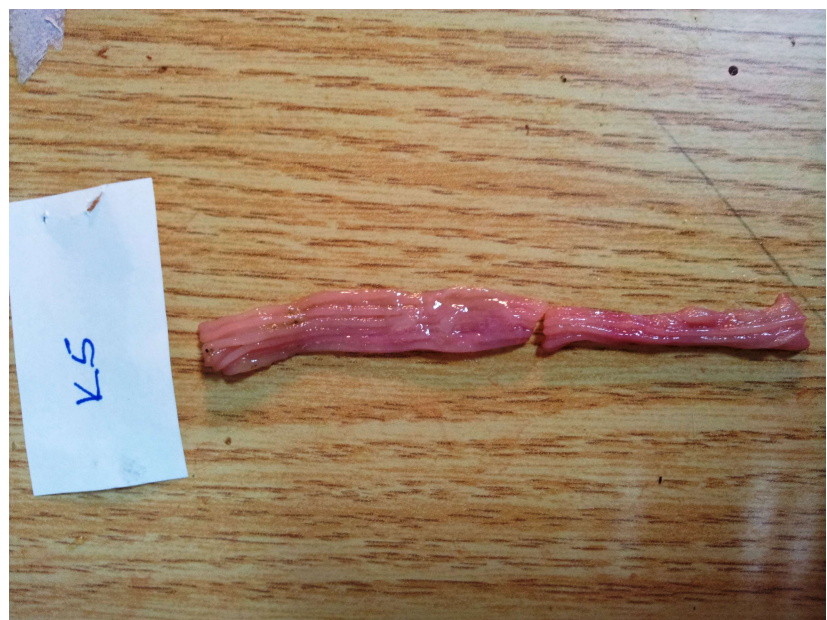

Figure 4a.

The proinflammatory mediators, TNF- $\alpha$ and IL- $1 \beta$ were elevated in colitis group compared to other groups ( $p<0,001, p<0,001$ respectively). On the other hand, TGF- $\beta$ was found significantly lower in colitis group compared to other groups $(p<0,001)$. TNF- $\alpha(p>0.12, \mathrm{IL}-1 \beta(p>0.16)$ and TGF- $\beta(p>0.44)$ levels did not show a significant difference between the groups of control, ALA and ALA-colitis (Table 1).

In colitis group (group 4), typical changes related to ulcerative colitis such as multiple ulcers and diffuse inflammation were noticed (Figure 1a). Histological examination revealed loss of epithelial cells with ulceration, goblet cell depletion, inflammatory cells in mucosa and around the crypts that were polymorphonuclear leukocytes and lymphocytes. ( $x 400, \mathrm{H}$ and $\mathrm{E})$ (Figure1b). In contrast, macroscopic and microscopic evaluation showed mild changes in ALA (Figure 2a, 2b), ALA-colitis (Figure 3a, 3b) and control groups (Figure 4a, 4b). Therefore, regarding macroscopic and microscopic features, significant difference were found between the colitis group compared to ALA-colitis group (Table 1$)(p<0.001)$.

In the present study, rats in colitis group produced a significant increase in lipid peroxidation levels in the colon, as measured by the formation of MDA. Similarly, the marked reduction in TAS levels in colitis group was found compared to control groups. Interestingly, TAS levels were markedly higher in ALA and ALA-colitis groups ( $p<0.001)$.

\section{DISCUSSION}

The results of the present study demonstrate that ALA administration considerably prevent the development of gut mucosal lesions induced by acetic acid, as confirmed by macroscopic examination, histological evaluation and biochemical assays as a measure of the extent of the inflammatory response and reactive oxygen metabolites (ROMs).

ALA is previously described as an ideal antioxidant because it possesses many beneficial characteristics, including specific free radical quenching,

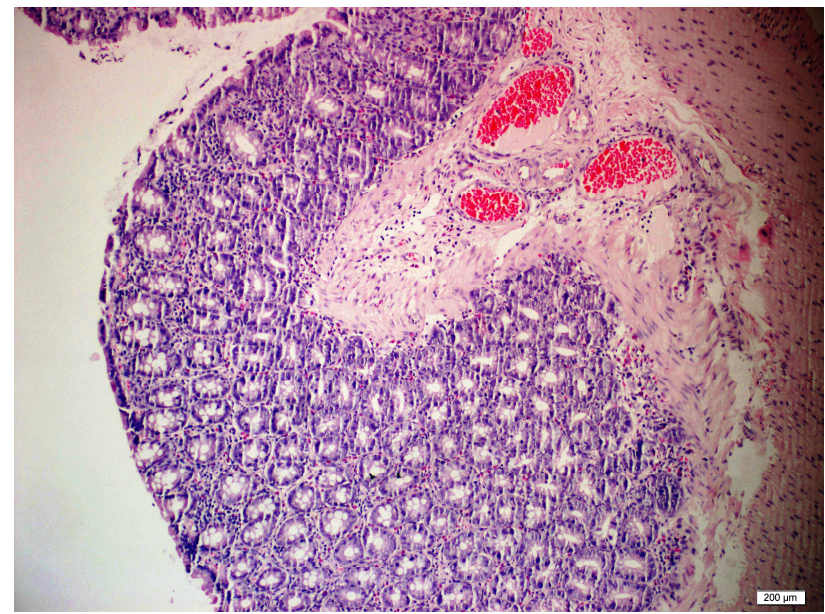

Figure 3b.

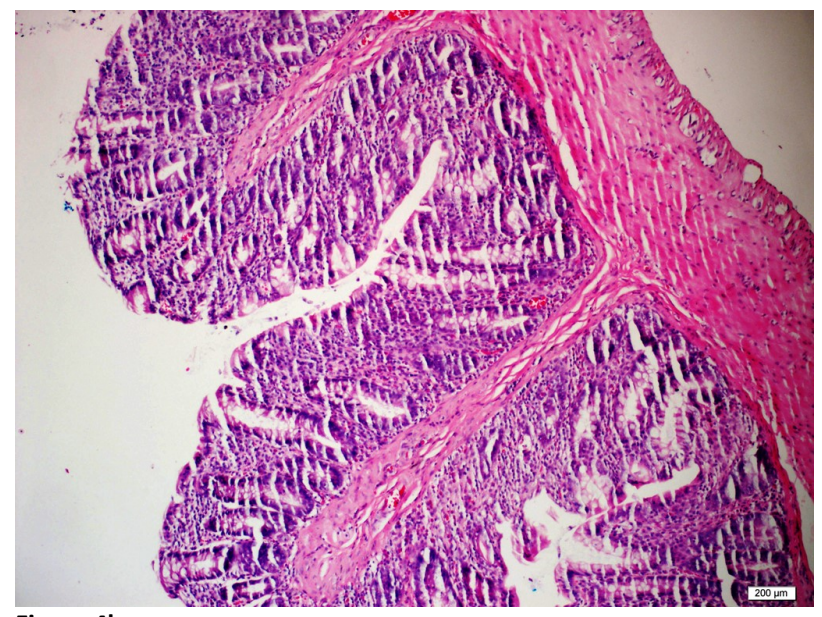

Figure 4b.

metal chelating activity, enhancing the antioxidant potency of other antioxidants, and suppressive effects on redox-sensitive gene expression.

ALA has also been shown to increase coenzyme Q10 and intracellular GSH levels (27). Due to its antioxidant activity, ALA administration has been demonstrated to be beneficial in a number of conditions including ischemiareperfusion injury, diabetes, cataract formation and radiation injury. More recently, Kolgazi et al. have shown that ALA was beneficial in rat-colitis model via suppression of ROMs (28).

In our study, the anti-inflammatory action of ALA in acetic acid-induced gut inflammation in rats seems to involve suppression of neutrophil accumulation, inhibition of ROM generation and lipid peroxidation, all of which would otherwise lead to impairment of cell integrity.

It is very clear that the increase of proinflammatory cytokines such as TNF$\alpha, \mathrm{IL}-1 \beta$ within colonic tissues plays a pivotal role in the pathogenesis of UC (29). Serum TNF- $\alpha$ and IL-1 $\beta$ concentration and colonic TNF- $\alpha$ and IL-1 $\beta$ mRNA expression levels are increased significantly in UC rats in correlation with the severity of disease in previous studies. It indicates that TNF- $\alpha$ and IL$1 \beta$ are closely involved in the immune abnormalities and inflammatory responses in UC. TGF- $\beta$ is an inhibitory cytokine, a key regulator in the maintenance of immune and inflammatory responses. Evidence suggests that TGF- $\beta$ acts together with other growth factors in protecting host tissue from fibrosis and intestinal ischemia and can help the mucosal healing in UC and Crohn's disease $(30,31)$. However, no correlation between TGF- $\beta$ serum concentrations and UC activity index was found in previous studies. Hence, the role of TGF- $\beta$ in UC is yet to be characterized. In our study, significantly elevated TNF- $\alpha$, IL-1 $\beta$ levels and declined levels of TGF- $\beta$ were observed in group 4 (colitis group). Accordingly, colitis in histological examination was in accordance with elevated cytokine levels. Interestingly, TNF- $\alpha, \mathrm{IL}-1 \beta$ and TGF- $\beta$ levels were not different between group 3 (ALA-Colitis) and control group. Significantly lower TNF- $\alpha$, IL-1 $\beta$ levels and mild histological changes in group 3 show the protective role of ALA from colitis. TNF- $\alpha$, IL-1 $\beta$ and TGF- $\beta$ levels in group 2 were not different from the control group in our study meaning that ALA has no hazardous effect on the normal colon. 
Increased myeloperoxidase activity, an indicator of infiltration of colon with polymorphonuclear leukocytes, mucosal dysfunction and tissue necrosis, in experimental colitis model has been found positively correlated with increase in tissue levels of MDA (32). MDA is an endogenous product of oxygen radical-induced lipid peroxidation that takes place as a consequence of the colonic oxidative insult $(33,34)$. Many studies have demonstrated that toxic mucosal injury in experimental colitis models can increase MDA levels and decreasing its levels by various agents used may be an indicator of treatment. Our results showed that ALA could significantly decrease the MDA levels of colonic tissue with AA-induced colitis.

TAS levels may give some information about the all antioxidants in the tissue. Although it has been associated with many clinical conditions such as allergic rhinitis (35), myocardial infarction (36), coronary artery calcification in type 1 diabetes (37), there is no data about relationship between IBD and TAS. In our study, we found that tissue TAS levels were markedly elevated in ALA-taking groups.

Protection of colonic mucosa is probably related, at least in part, to both the anti-inflammatory and antioxidant properties of ALA. If the present findings can be confirmed in a clinical setting, ALA may possibly have some therapeutic usefulness in the management of human UC.

\section{Conflict of interest}

No conflict of interest was declared by the authors.

\section{REFERENCES}

1. Saleh M, Trinchieri G. Innate immune mechanisms of colitis and colitis-associated colorectal cancer. Nat Rev Immunol 2011;11:920.

2. Strober, W., Ludviksson, B.R., Fuss, I.J., The pathogenesis of mucosal inflammation in murine models of inflammatory bowel disease and Crohn's disease. Ann. Intern. Med. 1998;128, 848-56.

3. Papadakis KA, Targan SR. Role of cytokines in the pathogenesis of inflammatory bowel disease. Annual Review of Medicine.2000;51:289-98

4. Carter MJ, Lobo AJ, Travis SP; IBD Section, British Society of Gastroenterology. Guidelines for the management of inflammatory bowel disease in adults. Gut. 2004;53 Suppl 5:V116.

5. Stange EF, Travis SPL, Vermeire S, Reinisch W, Geboes K, Barakauskiene $A$, et al . European evidence-based consensus on the diagnosis and management of ulcerative colitis: definitions and diagnosis. J Crohns Colitis 2008;2:1-23.

6. Reed L. From lipoic acid to multi-enzyme complexes. Protein Sci.1998; 7: 220-4

7. Packer L, Kraemer K, Rimbach G. Molecular aspects of lipoic acid in the prevention of diabetes complications. Nutrition 2001;17:888e95.

8. Shay KP, Moreau RF, Smith EJ, Smith AR, Hagen TM. Alpha-lipoic acid as a dietary supplement: molecular mechanisms and therapeutic potential. Biochim Biophys Acta. 2009;1790(10):114960.

9. Packer L, Roy S, Sen CK: Alpha-lipoic acid: a metabolic antioxidant and potential redox modulator of transcription. Adv Pharmacol 1997; 38: 79-101.

10. Biewenga GP, Haenen GR, Bast A: The pharmacology of the antioxidant lipoic acid. Gen Pharmacol 1997; 29: 315-31.

11. Bilska, A., Włodek, L., Lipoic acid - the drug of the future. Pharmacol. Rep. 2005;57, 570-7.

12. Ziegler D, Ametov A, Barinov A, Dyck PJ, Gurieva I, Low PA, et al. Oral treatment with alpha-lipoic acid improves symptomatic diabetic polyneuropathy: the SYDNEY 2 trial. Diabetes Care. 2006;29:2365-70.

13. Vasdev S, Gill V, Longerich L, Parai S, Gadag V. Salt-induced hypertension in WKY rats: prevention by alpha-lipoic acid supplementation. Mol Cell Biochem. 2003;254:319-26.

14. Thirunavukkarasu V, Anitha Nandhini AT, Anuradha CV. Lipoic acid attenuates hypertension and improves insulin sensitivity, kallikrein activity and nitrite levels in high fructose-fed rats. J Comp Physiol. 2004;174:587-92.

15. Zhang WJ, Bird KE, McMillen TS, LeBoeuf RC, Hagen TM, Frei B. Dietary alpha-lipoic acid supplementation inhibits atherosclerotic lesion development in apolipoprotein E-deficient and apolipoprotein E/low-density lipoprotein receptor- deficient mice. Circulation. 2008;117:421-8.
16. Zulkhairi A, Zaiton Z, Jamaluddin M, Sharida F, Mohd TH, Hasnah $B$, et al. Alpha lipoic acid possess dual antioxidant and lipid lowering properties in atherosclerotic-induced New Zealand white rabbit. Biomed Pharmacother. 2008;62:716-22.

17. Yang RL, Li W, Shi YH, Le GW. Lipoic acid prevents high-fat dietinduced dyslipidemia and oxidative stress: a microarray analysis. Nutrition. 2008;24:582-8.

18. Kamenova P. Improvement of insulin sensitivity in patients with type 2 diabetes mellitus after oral administration of alpha-lipoic acid. Hormones (Athens). 2006;5:251-8.

19. de Oliveira AM, Rondó PH, Luzia LA, D'Abronzo FH, Illison VK: The effects of lipoic acid and alpha-tocopherol supplementation on the lipid profile and insulin sensitivity of patients with type 2 diabetes mellitus: a randomized, double-blind, placebo-controlled trial. Diabetes Res Clin Pract 2011; 92: 253-60.

20. Min AK, Kim MK, Seo HY, Kim HS, Jang BK, Hwang JS, et al. Alphalipoic acid inhibits hepatic PAI-1 expression and fibrosis by inhibiting the TGF-beta signaling pathway. Biochem Biophys Res Commun. 2010;393:536-41.

21. Ying Z, Kampfrath $T$, Sun $Q$, Parthasarathy $S$, Rajagopalan $S$ Evidence that $\alpha$-lipoic acid inhibits NF-KB activation independent of its antioxidant function. Inflamm Res. 2011;60:219-25.

22. Cooper HS, Murthy SN, Shah RS, Sedergran DJ Clinicopathologic study of dextran sulfate sodium experimental murine colitis. Lab Invest. 1993; 69:238-49.

23. Morris GP, Beck PL, Herridge MS, Depew WT, Szewczuk MR, Wallace JL Hapten-induced model of chronic inflammation and ulceration in the rat colon. Gastroenterology. 1989; 96:795-803.

24. Appleyard CB and Wallace JL. Reactivation of hapten-induced colitis and its prevention by anti-inflammatory drugs. Am J Physio Gastrointest Liver Physiol 1995;269: G119-G125.

25. Hawinkels LJ, Verspaget HW, van Duijn W, van der Zon JM, Zuidwijk K, Kubben FJ, et al. Tissue level, activation and cellular localisation of TGF-b1 and association with survival in gastric cancer patients. British Journal of Cancer.2007; 97:398-404.

26. Lowry $\mathrm{OH}$, Rosebrough NJ, Farr A, Randall RJ. Protein measurement with the folin phenol reagent. J. Biol. Chem.1951;193:265-75.

27. Gorąca A, Huk-Kolega H, Piechota A, Kleniewska P, Ciejka E, Skibska B. Lipoic acid - biological activity and therapeutic potential.Pharmacol Rep. 2011;63:849-58.

28. Kolgazi M, Jahovic N, Yüksel M, Ercan F, Alican I. Alpha-lipoic acid modulates gut inflammation induced by trinitrobenzene sulfonic acid in rats. J Gastroenterol Hepatol. 2007;22:1859-65.

29. Baumgart DC, Carding SR. Inflammatory bowel disease: cause and immunobiology. Lancet. 2007;369:1627-40

30. Lawrance IC, Maxwell L, Doe W. Inflammation location, but not type, determines the increase in TGF-beta1 and IGF-1 expression and collagen deposition in IBD intestine. Inflamm Bowel Dis. 2001;7:16-26

31. Kanazawa S, Tsunoda T, Onuma E, Majima T, Kagiyama M, Kikuchi K. VEGF, basic-FGF, and TGF-beta in Crohn's disease and ulcerative colitis: a novel mechanism of chronic intestinal inflammation. Am J Gastroenterol. 2001;96:822-8.

32. Cuzzocrea S, McDonald MC, Mazzon E, Mota-Filipe $H$, Centorrino $\mathrm{T}$, Terranova ML, et al. Calpain inhibitor I reduces colon injury caused by dinitrobenzene sulphonic acid in the rat. Gut. 2001;48:478-8.

33. Pavlick KP, Laroux FS, Fuseler J, Wolf RE, Gray L, Hoffman J, et al. Role of reactive metabolites of oxygen and nitrogen in inflammatory bowel disease. Free Radic Biol Med. 2002;33:311 22.

34. Loguercio C, D'Argenio G, Delle Cave M, Cosenza V, Della Valle N, Mazzacca $G$ et al. Direct evidence of oxidative damage in acute and chronic phases of experimental colitis in rats. Dig Dis Sci. 1996;41:1204-11.

35. Emin O, Hasan A, Aysegul D, Rusen D. Total Antioxidant Status and Oxidative Stress and Their Relationship to Total IgE Levels and Eosinophil Counts in Children With Allergic Rhinitis J Investig Allergol Clin Immunol 2012;22: 188-192

36. Surekha RH, Srikanth BB, Jharna $P$, Ramachandra RV, Dayasagar $\mathrm{RV}$, Jyothy $\mathrm{A}$. Oxidative stress and total antioxidant status in myocardial infarction. Singapore Med J. 2007;48:137-42.

37. Valabhji J, McColl AJ, Richmond W, Schachter M, Rubens MB, Elkeles RS. Total antioxidant status and coronary artery calcification in type 1 diabetes. Diabetes Care. 2001;24:1608-13. 